\title{
Dinamika dan pola kekuasaan pemilik tempat kerja terhadap mahasiswa pekerja paruh waktu di Kota Malang
}

\author{
Siti Nur Azizah, Nanda Harda Pratama Meiji*, Nur Hadi, Elya Kurniawati \\ Universitas Negeri Malang, Jl. Semarang No. 5 Malang, Jawa Timur, Indonesia \\ *Penulis korespondensi, Surel: nanda.harda.fis@um.ac.id
}

Paper received: 01-05-2021; revised: 15-05-2021; accepted: 30-05-2021

\begin{abstract}
The phenomenon of students studying while working is not a sticky thing in society, many students choose to study while working for various reasons. Facing the world of work must be faced with the provisions of work regulations that part-time workers must be able to adapt, coming from the world of education and plunging into the world of work is not an easy thing because they have to divide their thoughts into several focuses. This study aims to describe and analyze the dynamics of parttime worker while working and how the power patterns exercised by workplace owners over parttime worker. The method used in this research is qualitative. The data collection method used indepth interviews and observations in the work environment of part-time worker. The research informants were selected purposively by requiring that they were in college while working part time. The results of the study explain that the owner of the workplace has a broader pattern of power and dominance due to his higher position than the worker, the power patterns including salaries below the minimum wage, binding work regulations, and policies that are more profitable for the workplace owner. The dynamics felt by part-time working students are also a challenge in terms of adapting to the world of work.
\end{abstract}

Keywords: dynamics; power patterns; part time worker

\begin{abstract}
Abstrak
Fenomena mahasiswa kuliah sambil bekerja bukanlah hal yang tabu di masyarakat, banyak sekali mahasiswa yang memilih untuk kuliah sambil bekerja dengan alasan yang bermacam-macam. Menghadapi dunia kerja pasti dihadapkan dengan ketentuan peraturan kerja yang harus bisa diadaptasi oleh mahasiswa pekerja paruh waktu, datang dari dunia pendidikan dan terjun ke dunia kerja bukan suatu hal yang mudah karena mereka harus membagi pikirannya menjadi beberapa fokus. Penelitian ini bertujuan untuk mendeskripsikan dan menganalisis mengenai bagaimana dinamika mahasiswa pekerja paruh waktu selama bekerja serta bagaimana pola kekuasaan yang dilakukan pemilik tempat kerja terhadap mahasiswa pekerja paruh waktu. Metode yang digunakan dalam penelitian ini adalah kualitatif. Metode pengumpulan data menggunakan wawancara mendalam beserta observasi di lingkungan kerja mahasiswa pekerja paruh waktu. Informan penelitian dipilih secara purposive dengan mensyaratkan bahwa mereka sedang kuliah sambil bekerja paruh waktu. Hasil penelitian menjelaskan bahwa pemilik tempat kerja memiliki pola kekuasaan dan dominasi lebih luas dikarenakan posisinya yang lebih tinggi daripada pekerja, pola kekuasaan tersebut diantaranya gaji dibawah UMR, peraturan kerja yang mengikat, serta kebijakan yang lebih banyak menguntungkan pemilik tempat kerja. Dinamika yang dirasakan mahasiswa pekerja paruh waktu juga menjadi tantangan dalam hal beradaptasi di dunia kerja.
\end{abstract}

Kata kunci: dinamika; pola kekuasaan; pekerja paruh waktu

\section{Pendahuluan}

Fenomena mahasiswa kuliah sambil bekerja bukanlah hal yang tabu lagi di masyarakat, banyak sekali mahasiswa yang memilih untuk kuliah sambil bekerja dengan alasan yang bermacam-macam, mulai dari untuk memenuhi kebutuhan ekonomi, mengisi waktu luang maupun mencari pengalaman (Mardelina \& Muhson, 2017). Mahasiswa yang memilih kuliah 
sambil bekerja memiliki tujuan untuk dapat hidup lebih disiplin, menjadi dewasa dan menciptakan peluang usaha (Dirmantoro, 2015). Pekerja paruh waktu atau istilah lainnya yaitu part time merupakan jenis pekerjaan yang sangat masih diminati di kalangan mahasiswa, hal tersebut dilihat berdasarkan data pada Badan Pusat Statistik yang menjelaskan bahwa keadaan angkatan kerja di Indonesia khususnya pekerja paruh waktu mengalami perkembangan yang stabil dari tahun ke tahun. Pada tahun 2018 di bulan Agustus, jumlah pekerja paruh waktu di Indonesia tercatat sekitar 27,37 juta. Kemudian mengalami peningkatan pada tahun 2019 di bulan Agustus, tercatat yaitu 28,41 juta (Lindy, 2006). Jenis pekerjaan yang memiliki banyak peminat dimana mahasiswa sebagai aktornya sehingga tidaklah mereka merasa kesulitan menjalani pekerjaan tersebut adalah pekerjaan paruh waktu atau part-time work (Acero, et al., 2020).

Pekerja paruh waktu merupakan pekerja yang bekerja kurang dari jam kerja pekerja waktu penuh (Fathoni, 2017). Berdasarkan penjelasan ILO, pekerja paruh waktu tergolong menjadi pekerja tidak penuh, dalam artian mereka bekerja dibawah jam kerja normal atau kurang dari 35 jam dalam seminggu. Fenomena mahasiswa pekerja paruh waktu ini tentu memiliki manfaat bagi mahasiswa itu sendiri, salah satunya mereka telah dilatih untuk mempersiapkan diri mereka dalam dunia kerja, menjadi lebih disiplin dan memiliki pengalaman yang berbeda tentunya. Namun, dibalik pengambilan keputusan mahasiswa untuk kuliah sambil bekerja tentunya ada resiko yang harus mereka hadapi. Salah satunya adaptasi mereka terhadap lingkungan kerja. Proses adaptasi merupakan respon dan tindakan manusia untuk melanjutkan kehidupannya di masa mendatang sebagai kelanjutan dari masa lalunya, selain itu adaptasi juga merupakan bentuk interaksi individu dengan lingkungannya (Winata et al., 2014).

Dalam lingkungan kerja, karyawan diharuskan untuk beradaptasi dan mematuhi peraturan yang telah diberikan atasannya. Lingkungan kerja adalah kondisi di sekitar perusahaan yang dapat mempengaruhi pelaksanaan tugas karyawan (Pajak \& Zirman, 2013). Pemilik usaha akan memberikan beberapa peraturan dan job desk yang harus dijalankan oleh pekerja, dengan begitu sistem yang dijalankan oleh suatu perusahaan maupun penyedia tempat kerja akan berjalan dengan teratur. Seperti menurut (Pajak \& Zirman, 2013) bahwasanya, perusahaan dan karyawan merupakan simbiosis mutualisme. Apabila karyawan berhasil melakukan tugasnya dan berdampak bagi perusahaan, maka keduanya akan saling diuntungkan. Bagi karyawan, keberhasilan kerja merupakan bukti kemampuannya mengembangkan diri dan juga rasa tanggung jawab terhadap kebutuhan hidupnya. Sedangkan bagi organisasi, hal tersebut merupakan jembatan bagi perusahaan untuk dapat lebih maju. Adaptasi pada lingkungan kerja tersebut berlaku pada segala lapisan penyedia tempat kerja salah satunya di wilayah Kec. Lowokwaru, Kota Malang Jawa Timur. Lowokwaru merupakan sebuah kecamatan di Kota Malang, sebelah utara berbatasan dengan kecamatan Karangploso, sebelah timur dengan kecamatan Blimbing, selatan dengan kecamatan Klojen dan barat dengan kecamatan Dau. Kecamatan Lowokwaru juga memiliki 12 kampus besar diantaranya Universitas Brawijaya, Institut Teknologi Nasional, Universitas Negeri Malang, Politeknik Negeri Malang, Universitas Islam Negeri Malang, Universitas Islam Malang, Universitas Muhammadiyah Malang, Universitas Gajayana Malang, STIE Malangkucecwara (ABM), Universitas Tribhuwana Tungga Dewi, Universitas Widyagama dan Stikes Widyagama Husada. Selain itu juga merupakan daerah perkantoran baik pemerintahan maupun perusahaan, sehingga banyak karyawan yang melepas penat sehabis bekerja dengan nongkrong di coffee shop. Lowokwaru juga masuk dalam bagian pusat kota, sehingga tidak heran jika selalu ramai 
(Faskafri, S., 2020). Berdasarkan letak yang strategis tersebut, seringkali menjadi kesempatan bagi mahasiswa untuk bekerja paruh waktu.

Dari penjabaran latar belakang diatas, maka dari itu dalam penelitian ini, peneliti memfokuskan pada bagaimana Dinamika dan Pola Kekuasaan Pemilik Tempat Kerja Terhadap Mahasiswa Pekerja Paruh Waktu di Kec. Klojen, Kota Malang Jawa Timur, untuk mengidentifikasi kegiatan-kegiatan yang dilakukan oleh para karyawan serta bagaimana bentuk pola kekuasaan pemilik tempat kerja terhadap karyawan paruh waktunya. Penelitian tentang hubungan pemilik tempat kerja dengan pekerja banyak dilakukan oleh para peneliti sebelumnya, yang pertama yakni penelitian yang dilakukan oleh Firdaus Anwar tahun 2016 dengan judul "Hubungan Sosial Bos dengan Anak Buah Dalam Usaha Pertambangan Emas di Nagari Lubuk Ulang Aling Selatan, Kecamatan Sangir Batang Hari, Kabupaten Solok Selatan". Penelitian ini menghasilkan bahwa antara bos dan anak buah di tambang emas ini saling membutuhkan dan membentuk suatu kerjasama yang kompleks dalam dunia kerja seperti (1) Kesepakatan Kerja (2) Gaji (3) Bonus dan hubungan diluar kerja pula seperti (1) silaturahmi (2) tempat curhat (3) persaudaraan (4) hutang piutang (Kementerian Kesehatan Republik Indonesia, 2016). Selanjutnya, penelitian yang dilakukan oleh Citra Asmara Indra pada tahun 2013 dengan judul "Implikasi Terbitnya Regulasi Tentang Pertimahan Terhadap Hubungan Bos dan Anak Buah" yang menghasilkan penelitian bahwa hubungan bos dengan anak buah, pemilik modal kecil atau menengah dapat dikatakan tidak mengikat secara emosional dikarenakan latar belakang yang sama. Hubungan kerjasama akan tetap berlangsung apabila hubungan tersebut memberikan keuntungan pada masing-masing pihak dan hubungan akan terputus secara begitu saja apabila sudah tidak ada yang diuntungkan tanpa ada konsekuensi apapun (Indra, 2013).

Permasalahan ini penting untuk dibahas dikarenakan setiap pemilik tempat kerja pasti memiliki dominasinya masing-masing entah hal tersebut menguntungkan maupun merugikan bagi para pekerjanya. Sehingga hal tersebut akan mempengaruhi bagaimana dinamika mahasiswa pekerja paruh waktu terhadap lingkungan kerjanya. Terlebih jika melihat karyawan adalah seorang mahasiswa, tentunya mereka harus beradaptasi karena dunia kerja dan kuliah merupakan hal yang baru bagi mereka. Selain itu, permasalahan ini penting untuk dibahas dikarenakan jumlah tenaga kerja lebih banyak daripada penyedia kerja sehingga memunculkan dinamika bagi mahasiswa di bawah kuasa pemilik tempat kerja.

\section{Metode}

Metode yang digunakan dalam penelitian ini adalah kualitatif, dengan tujuan untuk memahami suatu makna fenomena dari yang tampak maupun tidak tampak dalam dinamika mahasiswa pekerja paruh waktu di Kota Malang dalam menghadapi pola kekuasaan dari pemilik tempat kerja. Jenis penelitian ini merupakan jenis penelitian yang tepat dikarenakan dapat memahami suatu fenomena yang dialami oleh subjek penelitian seperti perilaku, persepsi, motivasi, tindakan dll. Secara holistik dan dengan cara mendeskripsikan dalam bentuk kalimat dan bahasa dalam konteks khusus yang alamiah dengan memanfaatkan beragam metode alamiah (Moleong, 2016). Kota Malang menjadi pilihan peneliti dikarenakan Kota Malang merupakan kota pendidikan dimana terdapat banyak universitas negeri maupun swasta yang memiliki jumlah mahasiswa berjumlah 247.027 (Kecamatan Lowokwaru dalam Angka 2019, 2019). Hal tersebut memudahkan peneliti dalam mencari informan mahasiswa pekerja paruh waktu dengan melihat pula angkatan kerja di Kota Malang berdasarkan pendidikan tertinggi yang ditamatkan. Waktu penelitian dilakukan pada 26 Februari-30 April 
2021 tepatnya di Kecamatan Lowokwaru Kota Malang. Metode pengumpulan data menggunakan wawancara mendalam beserta observasi. Informan penelitian dipilih secara purposive dengan mensyaratkan bahwa mereka sedang kuliah sambil bekerja paruh waktu. Informan berjumlah 15 orang ( 11 informan mahasiswa pekerja dan 4 informan pemilik tempat kerja). Informan tidak dibatasi dari tempat kerja maupun perguruan tinggi tertentu, hal tersebut untuk mengetahui perbedaan dinamika yang dirasakan setiap mahasiswa pekerja paruh waktu. Berikut data informan yang dipilih peneliti, nama informan sengaja tidak menggunakan nama asli serta nama tempat bekerja sengaja tidak disertakan dengan alasan privasi.

Tabel 1. Data Informan

\begin{tabular}{llllll}
\hline No & Nama & Umur & Jabatan & Lama bekerja & Penghasilan/bulan \\
\hline 1 & Fia & 23 tahun & Kasir & 1,5 tahun & Rp. 600.000 \\
2 & Salma & 20 tahun & Waiters & 1 tahun & Rp. 800.000 \\
3 & Putri & 20 tahun & Barista & 1 tahun & Rp. 1800.000 \\
4 & Lala & 21 tahun & Barista & 9 bulan & Rp. 1.000 .000 \\
5 & Amri & 22 tahun & Produksi & 3 bulan & Rp. 800.000 \\
6 & Ika & 21 tahun & Kasir & 6 bulan & Rp. 900.000 \\
7 & Rizqi & 22 tahun & Managemen & 2 tahun & Rp. 2.000 .000 \\
8 & Bara & 21 tahun & Kitchen Crew & 1 tahun & Rp. 1.200 .000 \\
9 & Yusaf & 22 tahun & Waiters & 1,5 tahun & Rp. 900.000 \\
10 & Ida & 21 tahun & Admin & 1 tahun & Rp. 1.000 .000 \\
11 & Farhan & 23 tahun & Waiters & 3 bulan & Rp. 700.000 \\
12 & Achmad & 25 tahun & Owner & 6 bulan & Rp. 10.000 .000 \\
13 & Fuad & 22 tahun & Owner & 2 tahun & Rp. 9.000 .000 \\
14 & Harianto & 23 tahun & Owner & 2 tahun & Rp. 60.000 .000 \\
15 & Rendra & 30 tahun & Owner & 2 tahun & Rp. 10.000 .000 \\
\hline
\end{tabular}

Uji validasi data dilakukan dengan triangulasi sumber. Analisis data dilakukan dengan tahap pengumpulan data, reduksi data serta penyajian data yang terstruktur.

\section{Hasil dan Pembahasan}

Pengangguran menjadi salah satu masalah utama terhadap pembangunan di Kota Malang, faktor penyebabnya dikarenakan adanya ketidakseimbangan antara pencari kerja dengan lapangan pekerjaan sehingga pertumbuhan ekonomi belum maksimal dalam menyerap tenaga kerja (Lindy, 2006). Tingkat perguruan tinggi telah menyumbangkan sebanyak 96.636 jiwa angkatan kerja pada tahun 2020 dan data tersebut menempati rangking kedua setelah data pekerja di tingkat SD Sederajat yang memiliki sebanyak 99.097 jiwa (No Title, n.d.). Hal tersebut berarti bahwa keberadaan mahasiswa yang memiliki tugas utama menyelesaikan pendidikan tidak menyurutkan keinginan mereka untuk tetap bekerja. Hal tersebut menjadi tantangan tersendiri bagi mahasiswa pekerja paruh waktu, melihat gaji yang didapat seringkali jauh dibawah UMR Kota Malang. Dilema tentu dirasakan oleh mahasiswa pekerja paruh waktu, disisi lain mereka tidak mendapatkan gaji yang seimbang dan harus menaati peraturan di tempat kerja namun juga masih membutuhkan pekerjaan tersebut. Dalam lingkungan kerja, karyawan diharuskan untuk beradaptasi dan mematuhi peraturan yang telah diberikan atasannya.

Pemilik usaha akan memberikan beberapa peraturan dan job desk yang harus dijalankan oleh pekerja, dengan begitu sistem yang dijalankan oleh suatu perusahaan maupun 
penyedia tempat kerja akan berjalan dengan teratur. Seperti menurut (Pajak \& Zirman, 2013) bahwasanya, perusahaan dan karyawan merupakan simbiosis mutualisme, apabila karyawan berhasil melakukan tugasnya dan berdampak bagi perusahaan maka keduanya akan saling diuntungkan. Bagi karyawan, keberhasilan kerja merupakan bukti kemampuannya mengembangkan diri dan juga rasa tanggung jawab terhadap kebutuhan hidupnya. Sedangkan bagi organisasi, hal tersebut merupakan jembatan bagi perusahaan untuk dapat lebih maju.

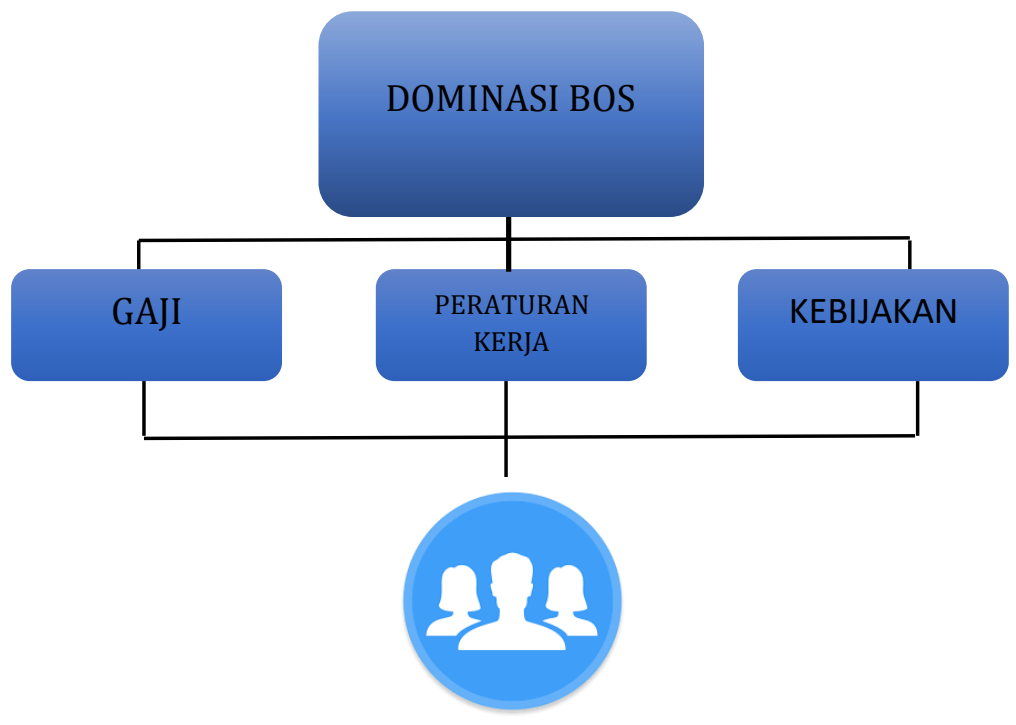

\section{Gambar 1. Bagan Dominasi Bos Terhadap Pekerja}

Dalam sebuah perusahaan maupun tempat kerja pasti terdapat konflik maupun kesalahpahaman antara bos dan karyawannya. Para pekerja yang tidak setuju dengan keputusan yang dibuat di dalam sebuah perusahaan, peraturan yang dibuat, maupun nilai-nilai yang dibuat akan mengakibatkan suatu konflik (Sri Rahayu, 2012). Bagan tersebut menjelaskan bahwa terdapat dominasi bos dalam lingkungan kerja. Pola kekuasaan pemilik tempat kerja dapat dilihat dari peraturan yang diberikan di tempat kerja tersebut, pemilik modal memiliki kuasa untuk mengatur pekerjanya supaya sesuai dengan tujuannya mendirikan bisnis. Pemilik modal memiliki kekuasaan untuk mengatur strategi perusahaan (Annoni, 2000).

Gaji, menjadi hal utama yang dapat dilihat dalam dominasi bos terhadap pekerjanya. Gaji disebut sebagai balas jasa dalam bentuk uang kepada karyawan/pekerja yang telah memberikan kontribusinya dalam pencapaian suatu perusahaan/organisasi (Hoeran, 2017). Pemilik modal juga memberikan bonus tiap bulannya kepada karyawan apabila penjualan usaha meningkat. Terdapat bonus tambahan lain juga kepada karyawan terbaik yang melakukan pekerjaan dengan maksimal, hal tersebut merupakan cara pemilik modal untuk meningkatkan kinerja karyawannya supaya karyawan satu sama lain bersaing untuk mendapatkan bonus. Setiap perusahaan maupun badan usaha seringkali memberikan bonus gaji disamping gaji pokok untuk meningkatkan produktivitas serta kinerja karyawannya, kriteria karyawan yang berhak mendapatkan bonus gaji adalah sikap kerja, tanggung jawab, kejujuran serta kehadiran (Manurung, 2017).

"bagi saya yang memang sedang mencari uang sekaligus kuliah begini, gaji 800 ribu perbulan itu sudah lumayan lah. Daripada tidak sama sekali mbak, soalnya kerjanya juga nyuci sepatu, mudah 
tapi susah juga kalau misalkan ada kesalahan soalnya yang tanggung jawab ganti itu ya karyawannya. Kadang gaji juga kepotong buat gantiin sesuatu yang rusak itu tadi" (wawancara Amri 2020).

Pemberian gaji pada tempat kerja di Kota Malang tidaklah menentu, seperti contoh jabatan kasir di tempat kerja A mendapatkan upah yang lebih sedikit daripada jabatan barista di tempat kerja B. Padahal jika diobservasi secara langsung, pekerjaan si kasir lebih sulit dan lebih melelahkan dikarenakan tempat ia bekerja selalu ramai akan pengunjung. Sehingga hal tersebut juga menjadi sebuah dilema yang tidak ada habisnya, mahasiswa pekerja paruh waktu harus menimbang-menimbang secara matang sebelum terjun ke dunia kerja yang akan mereka dapatkan.

"kalau udah gajian saya kan ngumpulin anak-anak, terus sengaja ngasih tau siapa yang dapat bonus tambahan bulan ini itu di depan anak-anak supaya mereka yang gak dapet jadi makin terpacu untuk dapat bulan depannya. Kriteria untuk mendapatkan bonus karyawan terbaik itu soal bagaimana kinerja mereka selama sebulan, absensi dan juga cak cek apa gak kerjanya, kepekaan dan juga kejujurannya mbak. Dan cara ini menurut saya efektif dimasukkan dalam sistem pekerjaan" (wawancara Pak Harianto selaku owner, 2021).

Sedangkan menurut pemilik usaha sendiri, gaji yang diterima oleh karyawan tidak menjadi suatu masalah dikarenakan adanya sistem bonus pada tiap bulannya tergantung penghasilan dari penjualan per bulannya. Adanya sistem bonus bagi karyawan teladan juga diberikan oleh bos karena hal tersebut dianggap efektif untuk menciptakan kompetisi yang sehat antar karyawan satu dengan yang lain. Bonus tambahan diberikan kepada karyawan yang melakukan pekerjaan dengan maksimal. Setiap perusahaan maupun badan usaha seringkali memberikan bonus gaji disamping gaji pokok untuk meningkatkan produktivitas serta kinerja karyawannya, kriteria karyawan yang berhak mendapatkan bonus gaji adalah sikap kerja, tanggung jawab, kejujuran serta kehadiran (Manurung, 2017).

Tabel 2. Daftar Gaji Pekerja Paruh Waktu

\begin{tabular}{lllll}
\hline No & Nama & Umur & Jabatan & Gaji/bulan \\
\hline 1 & Fia & 23 tahun & Kasir & Rp. 600.000 \\
2 & Salma & 20 tahun & Waiters & Rp. 800.000 \\
3 & Putri & 20 tahun & Barista & Rp. 1800.000 \\
4 & Lala & 21 tahun & Barista & Rp. 1.000 .000 \\
5 & Amri & 22 tahun & Produksi & Rp. 800.000 \\
6 & Ika & 21 tahun & Kasir & Rp. 900.000 \\
7 & Rizqi & 22 tahun & Managemen & Rp. 2.000 .000 \\
8 & Bara & 21 tahun & Kitchen Crew & Rp. 1.200 .000 \\
9 & Yusaf & 22 tahun & Waiters & Rp. 900.000 \\
10 & Ida & 21 tahun & Admin & Rp. 1.000 .000 \\
11 & Farhan & 23 tahun & Waiters & Rp. 700.000 \\
\hline & UMK/UMR Kota & Rp. $2.970 .502,73$ & \\
\hline
\end{tabular}

Berdasarkan tabel diatas, mahasiswa pekerja paruh waktu di Malang memiliki gaji ratarata dibawah UMR. Hal tersebut dikatakan tidak seimbang, meskipun jam kerja pekerja paruh waktu hanyalah 8 jam kerja tetapi produktivitas yang dihasilkan memiliki kemungkinan lebih baik dikarenakan kelelahan yang dihasilkan, tidak seperti pekerja full time yang memiliki jam kerja lebih lama (Rabbani, 2019). Selain upah yang kecil, keberadaan pekerja paruh waktu juga mengalami diskriminasi maupun kondisi kerja yang tidak layak dikarenakan tidak adanya 
sistem jaminan sosial maupun serikat kerja yang mengakibatkan posisi mereka rendah, sehingga rentan mengancam keselamatan kerja (Hukum et al., n.d.). Gaji dibawah UMR menjadi suatu bentuk dominasi bos terhadap pekerjanya, bos memiliki keuntungan dikarenakan memberikan upah yang rendah, sedangkan pekerja paruh waktu menerima hal tersebut dengan pikiran bahwa upah yang diberikan sudah termasuk lumayan daripada tidak bekerja sama sekali.

Peraturan Kerja, merupakan kondisi di sekitar lingkungan kerja yang dapat mempengaruhi kinerja karyawan dalam bekerja. Kondisi lingkungan yang menyenangkan dapat membuat karyawan menjadi nyaman dan dapat menyelesaikan pekerjaan dengan baik, begitupun sebaliknya. Meskipun hal tersebut menjadi faktor penting, akan tetapi pada era modern ini masih banyak perusahaan yang masih menyepelekan kondisi lingkungan kerja (Prakoso, 2014). Di awal penerimaan karyawan baru, pemilik usaha memiliki kewajiban untuk menjelaskan peraturan serta informasi terkait pekerjaan seperti jam kerja, gaji, bonus, serta peraturan apa saja yang harus dipatuhi pekerja. Maka dari itu, mayoritas tempat kerja memiliki masa pelatihan atau training yang bertujuan meningkatkan kinerja karyawan dengan mengajarkan karyawan keterampilan dasar (Kerja, 2020).

Tidak hanya pekerja paruh waktu, seluruh pekerja pada dasarnya akan tunduk terhadap peraturan yang sudah dibuat atasan di tempat kerja. Disiplin dalam bekerja muncul berdasarkan niat dari masing-masing kesadaran diri individu, tidak dapat dipungkiri ketika memasuki dunia kerja banyak peraturan yang tidak sesuai dimana hal tersebut bertentangan dengan diri sendiri maupun norma di masyarakat yang menyebabkan adanya pertentangan. Sebagai pekerja, memiliki kewajiban untuk menyesuaikan dengan hal tersebut, sebagai tujuan peningkatan Sumber Daya Manusia dalam lingkungan kerja yang efektif (Pajak \& Zirman, 2013).

Kebijakan, pekerja paruh waktu belum memiliki undang-undang yang jelas dan belum ada UU yang mengatur mengenai pekerjaan paruh waktu. Pasal 99 UUTK menyatakan bahwa "setiap pekerja berhak mendapatkan jaminan sosial tenaga kerja", melihat kata "setiap pekerja" memungkinkan bahwa pekerja paruh waktu masuk ke dalam pasal tersebut karena tidak ada keterangan yang jelas dalam pasal tersebut antara pekerja penuh, paruh waktu maupun yang lainnya sehingga pekerja paruh waktu dapat berlindung dalam pasal tersebut dan mendapatkan hak yang bernama jaminan sosial. (Hukum et al., n.d.). Pekerja yang memiliki perjanjian kontrak serta jam kerja diluar ketentuan jam kerja tentu memiliki kerisauan terkait kesejahteraan di tempat kerja, hal tersebut mengakibatkan Hari Buruh pada tanggal 1 Mei selalu ramai akan aksi (Rabbani, 2019).

Seperti pada peristiwa Omnibus Law pada Oktober 2020 yang mengakibatkan buruh di Indonesia serentak melakukan perlawanan di depan masing-masing gedung DPR, beberapa pasal Omnibus Law yang merugikan diantaranya menetapkan UMP sebagai satu-satunya acuan gaji, memangkas pesangon jika pemilik usaha melakukan PHK (Pemutusan Hubungan Kerja), penghapusan izin/cuti khusus serta masih banyak pasal lain yang merugikan yang tentunya merugikan buruh. Keberadaan pekerja paruh waktu semakin merasakan dilema dengan adanya kebijakan ini dan memberikan pengusaha peluang lebih dalam mengatur kebijakan. 


\subsection{Dinamika Mahasiswa Pekerja Paruh Waktu}

Dinamika merupakan interaksi antar anggota yang satu dengan yang lain, yang terjadi secara dinamis di dalam kehidupan masyarakat (Rusmana, 2004). Dalam dinamika kehidupan, perubahan tidak hanya terjadi pada diri manusia, melainkan juga terjadi pada sistem yang juga dibuat oleh manusia itu sendiri. Sebuah konsep yang kita perlukan apabila ingin mengkaji proses perubahan masyarakat baik dalam ranah sosiologis maupun antropologis disebut dengan dinamika sosial. Menurut Rusmana (2004) diantara perubahan-perubahan masyarakat, konsep tersebut dapat dibedakan menjadi lima, yaitu: 1) Internalisasi, sosialisasi dan enkulturasi, 2) Evolusi kebudayaan (proses perkembangan manusia yang sederhana), 3) Difusi (proses penyebaran kebudayaan secara geografis), 4) Akulturasi dan asimilasi, dan 5) Inovasi (proses pembaruan dari sebuah penemuan).

Transisi pemuda dalam menghadapi dunia pendidikan menuju dunia kerja menjadi suatu tolak ukur keberhasilan mereka menuju kedewasaan. Dalam era modern, pemuda harus menghadapi kondisi yang tidak stabil yang mengakibatkan berbagai macam resiko dan memunculkan rule of the game dalam dunia kerja. Hal tersebut menjadi pembahasan penting dalam proses transisi pemuda atau zigzag journey dari masa dunia pendidikan menuju dunia kerja (Kuslarassakti \& Sutopo, 2020).

Seiring perkembangan zaman, masyarakat akan mengalami individualisasi institusi yaitu perubahan masyarakat dari awalnya mereka merupakan masyarakat institusi menjadi masyarakat individu (Sejarah et al., 2020). Hal tersebut juga terjadi pada dinamika kehidupan mahasiswa pekerja paruh waktu dimana mereka harus bisa struggling lalu perlahan lepas dari orang tua dan menjadi pribadi yang mandiri. Menjadi buruh di bawah kekuasaan pemilik modal mengharuskan mereka berpartisipasi secara langsung maupun tidak langsung dalam proses produksi. Buruh menjual jasanya dan melakukannya secara kolektif, sehingga seringkali buruh tidak menghargai dirinya sendiri secara individual karena terbiasa berada dalam lingkungan yang kolektif. Hal tersebut dikarenakan adanya hubungan ketergantungan antara pemilik kekuasaan dengan buruh yaitu dalam hal upah, demi keberlangsungan hidup (Kirom, 2013).

"iya disini ada sistem absen mbak, tiap karyawan punya paswordnya sendiri-sendiri terus pake foto selfie juga. Kalau terlambat 5 menit potong gaji setengah. Gak adil sih menurutku, soalnya Cuma 5 menit loh telat dan harus dipotong setengah gajinya sedangkan kita biasanya kalau close itu melebihi jam yang udah ditentukan dengan alasan sayang ada pelanggan yang masih mau makan" (wawancara Ika 2020).

"sistem absen disini tetep ada mbak, tapi aku sama temen-temen seringnya tidur di MES biar gampang aja jadi gak terlalu buru-buru kalau berangkat kerja" (wawancara Al 2020).

Dinamika pada mahasiswa pekerja paruh waktu memiliki pengalaman yang berbeda antara satu sama lain. Bergelut dalam dunia pendidikan dan pekerjaan menjadi tantangan tersendiri bagi mereka. Menjadi pekerja yang berada dibawah kuasa bos menjadikan mereka memiliki penilaian tersendiri kepada bosnya, dan hal tersebut tergantung bagaimana sistem kerja yang dilakukan oleh masing-masing bos. Dalam sebuah perusahaan maupun tempat kerja pasti terdapat konflik maupun kesalahpahaman antara bos dan karyawannya. Para pekerja yang tidak setuju dengan keputusan yang dibuat di dalam sebuah perusahaan, peraturan yang dibuat, maupun nilai-nilai yang dibuat akan mengakibatkan suatu konflik (Sri Rahayu, 2012). Secara teoritis, adanya ketergantungan antar pekerja dengan pemilik kekuasaan terjadi 
dikarenakan adanya industrialisasi yang menyebabkan pekerja memikirkan mengenai kesejahteraan di luar kekuasaan yang melingkarinya. Kesejahteraan mengenai keselamatan kerja, upah/gaji dan lain sebagainya. Oleh karena itu, industrialisasi mendorong buruh untuk membentuk serikat pekerja yang memperjuangkan keadilannya (Kirom, 2013).

Modernitas menjadikan pemuda mengalami resiko ketidakpastian akan masa depan dan memberikan tantangan tersendiri kepada mereka ketika memasuki dunia kerja yang sesungguhnya. Sehingga diperlukan adanya negosiasi antara pemuda dengan keluarga terkait keputusan dalam dunia kerja supaya pemuda memiliki arahan dan persetujuan dalam menghadapi masa depan, selain itu diperlukan adanya reflektivitas yang tinggi dengan cara memperluas mobilitas dan jaringan guna menghadapi resiko di masa yang akan datang (Kuslarassakti \& Sutopo, 2020).

Menurut Braverman (1974) Pekerja Detail yang disampaikan oleh Braverman yang memiliki arti bahwa di setiap tempat kerja memiliki spesialisasi sendiri-sendiri dan tugas masing-masing. Karyawan yang memiliki kemampuan lebih akan mendapatkan gaji lebih tinggi daripada karyawan yang lain, namun dalam pandangan kapitalis modern, ia lebih memilih sejumlah kecil pekerja diluar pekerja spesialis yang akan menyelesaikan pekerjaan secara utuh. Disisi lain bagi Braverman "pekerja tak akan sukarela mengabdikan dirinya sebagai pekerja detail seumur hidup" maka dari itu inilah kontribusi kapitalis, alasan kapitalis melakukan hal tersebut adalah: 1) Peningkatan kontrol manajemen, dengan adanya spesialisasi di tempat kerja maka akan mempermudah dalam mengontrol pekerja dibandingkan mengontrol pekerja dalam skala keterampilan yang luas. 2) Meningkatkan produksi, dengan adanya pembagian tugas maka pekerja akan lebih fokus dengan jobdesk nya sendiri dan menghasilkan lebih banyak hasil. 3) Membayar tinggi pada tenaga spesialis namun memiliki banyak cadangan pada tenaga kerja biasa dan membayar dengan lebih murah. 4) Diluar hal tersebut, spesialisasi bukanlah alat kontrol memadai bagi kapitalis dan manajer. Terdapat manajemen teknis dan ilmiah yang menjadi cara terbaik untuk mengendalikan tenaga kerja.

Cara diatas merupakan salah satu cara dari kapitalis dalam mencari keuntungan, fenomena tersebut juga terdapat di salah satu informan bernama Ika yang memiliki jabatan kasir di tempat kerjanya.

“jobdesk disini jelas pasti berbeda mbak. Tapi kadang saya sebagai kasir itu banyak diemnya, soalnya saya ngekasir itu kan kalau ada yang beli aja terus waiters disini juga sudah ada sendiri, jadi ya udah kebanyakan diem dibandingkan yang punya jobdesk masak, mereka selalu gerak terus menerus. Kadang juga pernah omong-omongan sama temen-temen sih kalau jobdesknya memberatkan salah satu pihak tapi bayarannya sama. Jadi solusi dari bos biasanya nambah karyawan baru supaya jobdesk yang dirasa berat bisa lebih ringan" (wawancara Ika 2021).

"gaji bagian dapur di tempat kerjaku ini sedikit mbak, serius. Gak imbang sama kerjanya mereka. Mereka udah beberapa kali minta kenaikan ke bos tapi masih molor tu dinaikinnya terus akhirnya baru bulan kemarin gaji mereka naik jadi 2 juta" (wawancara Salma 2021).

Pernyataan dari Ika menjelaskan bahwa dari adanya pembagian kerja (pekerja detail) tidak selamanya menguntungkan, hal tersebut mengakibatkan munculnya kecemburuan sosial oleh pekerja lain yang memiliki jobdesk lumayan berat tetapi dengan gaji yang sama. Ketidakseimbangan dan ketidakadilan upah tersebut mengakibatkan pekerja mencari solusi 
kepada bos, dan pada situasi seperti ini bos tidak akan menaikkan gaji secara langsung dengan alasan klasik yaitu butuh waktu sebagai pertimbangan.

\subsection{Pola Kekuasaan Pemilik Tempat Kerja}

Kekuasaan merupakan suatu dasar bagi seseorang di dalam kehidupan sosial dan terdapat penekanan di dalamnya. Ketika seseorang memiliki keinginan untuk mencapai suatu tujuan yang diinginkan oleh orang banyak pula, maka seseorang itu harus memiliki kekuasaan yang dominan. Faktor yang mendorong seseorang untuk berkuasa adalah faktor dari ingin memperoleh kekuasaan itu sendiri, entah itu faktor internal maupun eksternal (Sihombing, 2017). Suatu wewenang dapat efektif jika terdapat kekuasaan yang nyata, akan tetapi sering kali kekuasaan dipegang tidak hanya oleh satu pemilik maupun satu tempat. Dalam masyarakat yang kecil, kekuasaan dipegang oleh beberapa kelompok di berbagai bidang, sehingga konsep pemegang kekuasaan lambat laun diartikan dengan orang yang memegangnya (Moeis, 2008).

Pemilik modal memiliki caranya tersendiri dalam melakukan pola kekuasaan kepada karyawan, hal tersebut dapat disadari secara langsung maupun tidak langsung. Unsur eksploitasi dapat dilihat dari sistem kerja yang diatur oleh pemilik kekuasaan dan buruh tidak memiliki hak dalam kegiatan produksi, mereka bekerja dibawah komando bos (Sejarah et al., 2020). Harry Braverman (1974) menyatakan bahwa dalam proses tenaga kerja dan eksploitasi buruh merupakan inti dari teori Marxian. Dalam kapitalisme modern, Braverman menyatakan bahwa sebenarnya tak seorangpun diantara tenaga kerja yang memiliki alat produksi. Braverman pun melihat mesin sebagai alat pengontrol pekerja, keterampilan pekerja lebih ditujukan untuk melayani mesin daripada mengembangkan diri pekerja itu sendiri. Pekerja menjadi dikontrol oleh mesin dan tidak mengontrol pekerjaan.

Hal tersebut menjadi mudah bagi manajemen untuk melakukan monopoli karena akan lebih mudah mengontrol alat dan mesin daripada mengontrol pekerja yang notabennya manusia. Pekerja hanya memiliki pengaruh sedikit dalam pengambilan keputusan, manajemen tersebut melakukan monopoli untuk mengatur setiap langkah pekerja. Hingga akhirnya pekerja dibiarkan tanpa keterampilan dan pengetahuan yang bermakna. Braverman menganggap "kelas buruh" bukan sebagai sekelompok orang maupun pekerjaan tertentu, melainkan pernyataan tentang pembelian dan penjualan tenaga kerja. Kapitalisme monopoli di era modern ini tidak lagi mengedepankan harga dalam hal persaingan, melainkan bergeser pada bidang penjualan seperti periklanan pengemasan dengan cara yang kreatif untuk melakukan kompetisi.

"penggunaan alat ini ya pasti normal kan mbak, masa saya harus nggiling kopi sendiri hehe. Dari awal memang karyawan disuruh adaptasi sama alat-alat disini selain adaptasi sama kru yang lain. Kalau dibilang nggak bisa berkembang karena fokus sama alat sih ndak juga, soalnya saya jadi bisa belajar alat baru" (wawancara Putri 2021).

"agak susah sih awal-awal kalo adaptasi sama alat baru soalnya kan alat disini bukan alat masak pada umumnya karena disini kan modelnya makanan jepang gitu, tapi lama kelamaan ya bisa karena diajarin, disini termasuk selalu upgrade kalau perihal alat-alat gitu soalnya kayak gimana ya bos saya itu. Suka sama perintilan-perintilan anyar gitu lo mbak. Kadang malah saya belum pernah lihat alat itu sama sekali selama ini dan baru tau di tempat kerja saya juga" (wawancara Ika 2021). 
Berdasarkan pernyataan informan, penggunaan alat dan mesin telah digunakan di hampir semua tempat kerja karena pada dasarnya produksi dihasilkan dengan alat tersebut, meskipun manusia bisa melakukannya tetapi pemilik modal memilih untuk membeli alat dan mesin yang meskipun harganya mahal tetapi dapat meningkatkan hasil produksi. Hal tersebut juga berdampak pada kefokusan pekerja, dimana mereka akan lebih fokus kepada penggunaan alat, kesehatan alat serta kebersihan alat daripada dengan kemampuan tangannya sendiri. Menurut Braverman (Ritzer, 2008) kapitalisme monopoli serta pemilik modal melakukan pengendalian manajerial yang artinya menyerahkan tugas pengawasan dan mengontrol tenaga kerja melalui manager. Cara kapitalis mengendalikan tenaga kerja yang sedang dipekerjakan adalah melalui manajer sebagai pengendali tenaga kerja. Braverman mendefinisikan manager sebagai proses pengendalian tenaga kerja di dalam sebuah perusahaan. Braverman memusatkan perhatian pada cara manajer mengendalikan tenaga kerja dengan memanfaatkan spesialisasi tenaga kerja. Seluruh masyarakat pasti memiliki pembagian kerja atau perannya masing-masing, sama halnya seperti karyawan di sebuah perusahaan. Namun Braverman meyakini bahwa pembagian kerja di dalam masyarakat akan meningkatkan individualisme dan pembagian kerja dalam perusahaan akan menciptakan malapetaka.

Seperti narasi yang disampaikan oleh Rizqi, mahasiswa yang memegang bagian manajemen di tempat kerjanya:

"aku lebih sering di kantor daripada di toko sih mbak, tugasku ya ngecek temen-temen soalnya jaraknya juga gak jauh-jauh amat. Kondisi kerja di toko sudah kondusif, mereka udah deket banget sama pihak kantor dan jobdesk disini juga sudah diatur jadi mereka fokus dengan bidangnya masing-masing. Tanggung jawab jadi manager gini ya berat loh, apalagi yang diatur udah kayak temen sendiri. Sedangkan kita harus profesional ketika laporan ke bos" (wawancara Rizqi 2021).

Menjadi profesional dalam pekerjaan sekaligus humble kepada rekan kerja menjadi tugas multitasking sebagai manager di tempat kerja. Hal tersebut menjadi tantangan tersendiri dan dapat menjadi pemicu adanya konflik dikarenakan adanya perbedaan prinsip maupun pendapat antar rekan kerja. Rizqi juga menyatakan bahwa jobdesk di tempat kerja yang sudah diberikan menjadikan rekan kerjanya fokus dengan hasil produksinya sendiri daripada interaksi antar sesama rekan kerja. Manager menjadi perantara bos dalam hal laporan kegiatan selama bekerja, laporan yang diberikan haruslah sama dengan realita yang terjadi di lingkungan kerja.

\subsubsection{Pola Kekuasaan dari Sudut Pandang Mahasiswa}

Beberapa peraturan di tempat kerja dianggap tidak memberatkan dan beberapa kebijakan dianggap kurang menguntungkan bagi mahasiswa. Dinamika tersebut menjadi suatu pola di dalam lingkungan kerja. Pola kekuasaan pemilik tempat kerja dapat dilihat dari peraturan maupun kebijakan yang diberikan di tempat kerja tersebut, pemilik modal memiliki kuasa untuk mengatur pekerjanya supaya sesuai dengan tujuannya mendirikan bisnis. Pemilik modal memiliki kekuasaan untuk mengatur strategi perusahaan (Annoni, 2000).

Hubungan sosial yang baik dapat terwujud akibat terjalinnya komunikasi yang baik pula dari pihak atasan dan karyawan. Hubungan sosial yang terjalin dengan baik dapat menguntungkan kedua belah pihak diluar ranah pekerjaan juga. Dasar hubungan pemilik modal adalah terletak pada kemampuan ekonomi yang dimiliki, sebaliknya buruh tidak memiliki kemampuan kekuasaan tersebut sehingga ia membalas jasa dengan kesetiaan serta kinerja. Unsur timbal balik tersebut lah yang membedakan antara bos dan buruh. Perbedaan 
status sosial tersebut tidak menyebabkan jarak antara bos dan buruh karena acuan kehidupan bermasyarakat adalah terletak pada nilai dan norma (Subang, n.d.). Selain menjadi tempat bekerja dan mencari uang, hubungan antara bos dan karyawan memiliki kedekatan diluar ranah pekerjaan. Diantaranya menjadi tempat curhat, berbagi ilmu dan merasa memiliki kedekatan seperti keluarga sendiri. Lingkungan kerja yang nyaman akan meningkatkan kinerja karyawan dan memberikan pengaruh motivasi baik (Prakoso, 2014).

"baju yang tak pake ini loh mbak, panas pol kainnya. Kombor-kombor juga modelnya. Aku pernah pas ngekasir itu ngejatuhin tab gara-gara tabnya kecantol baju. Lah akhire malah aku sama tementemen harus ganti tamperglasnya, menurutku sih itu juga salah bosnya kenapa kok gak memberikan kenyamanan ke karyawannya, tapi kita juga Cuma bisa ngasi saran toh, diterima ya alhamdulillah gak diterima ya dirasakan aja" (wawancara Ikha 2020).

"Nyaman banget kerja disini mbak, karena seperti berasa seperti keluarga, tidak ada jarak antara owner dan pegawai, mereka kasih ilmu-ilmu baru yang banyak, memberikan bonus lembur dan tiap 3 bulan sekali mereka ada jadwal untuk piknik bersama-sama. Mereka saling support pegawai seperti saudara, mengenalkan teman2nya sesama owner agar relasi kita bertambah juga, banyak belajar di dunia pekerjaan yang sangat berasa hasilnya" (wawancara Bela 2020).

"Bos saya itu orangnya emang pendiem dan kurang dekat sama karyawan-karyawannya. Banyak karyawan yang tiba-tiba 1 hari masuk kerja udah resign karena bos itu kurang tegas, seharusnya ada perjanjian kontrak gitu kan enak. Dulu itu dia orangnya tega an banget, yang paling banyak dipikirin Cuma kenyamanan karyawannya aja. Hubungan kita sebatas bos dan karyawan aja. Kalau memang ada hal yang ngganjel sebenernya sih si bos santai aja untuk sharing. Tapi aku sebagai karyawan yang kurang deket jadi kayak sungkan dan males juga mau ngobrol" (wawancara Ika 2020)

Sudut pandang mengenai bos bagi setiap mahasiswa yang bekerja memiliki arti yang berbeda-beda, hal tersebut tergantung dari bagaimana perlakuan bos dan kedekatan bos dengan karyawannya. Namun dari beberapa informan, banyak yang memberikan pernyataan bahwa sistem yang diberikan kebanyakan kurang menguntungkan dan kedekatan yang terjalin hanya sebatas profesional kerja saja. Tidak hanya itu, beberapa mahasiswa yang memiliki jabatan tinggi di tempat kerja juga memiliki pengalaman lebih sebagai seorang manajer yang harus mengatur dan mengawasi jalannya kegiatan di lingkungan kerja.

Menurut Braverman (1974) Manajemen Teknis dan Ilmiah, manajer akan melakukan pengawasan terhadap karyawan dengan cara mengumpulkan pekerja dalam satu ruangan, menerapkan sistem jam kerja, mengawasi pekerja, menginterupsi peraturan dan menetapkan cara bekerja yang tepat untuk menghasilkan produksi yang maksimal. Pekerja hanya memiliki pengaruh sedikit dalam pengambilan keputusan, manajemen tersebut melakukan monopoli untuk mengatur setiap langkah pekerja. Hingga akhirnya pekerja dibiarkan tanpa keterampilan dan pengetahuan yang bermakna. Braverman pun melihat mesin sebagai alat pengontrol pekerja, keterampilan pekerja lebih ditujukan untuk melayani mesin daripada mengembangkan diri pekerja itu sendiri. Pekerja menjadi dikontrol oleh mesin dan tidak mengontrol pekerjaan. Hal tersebut menjadi mudah bagi manajemen untuk melakukan monopoli karena akan lebih mudah mengontrol alat dan mesin daripada mengontrol pekerja yang notabennya manusia.

Seperti pernyataan yang disampaikan oleh Ika selaku mahasiswa semester 7 yang bekerja sebagai kasir di salah satu tempat makan di Kota Malang. 
"agak susah sih awal-awal kalo adaptasi sama alat baru soalnya kan alat disini bukan alat masak pada umumnya karena disini kan modelnya makanan jepang gitu, tapi lama kelamaan ya bisa karena diajarin, disini termasuk selalu upgrade kalau perihal alat-alat gitu soalnya kayak gimana ya bos saya itu. Suka sama perintilan-perintilan anyar gitu lo mbak. Kadang malah saya belum pernah lihat alat itu sama sekali selama ini dan baru tau di tempat kerja saya juga" (wawancara Ika 2021).

Pernyataan dari Ika menyatakan bahwa ketika pemilik tempat kerja memberikan alat baru, maka ia beserta teman-temannya secara tidak langsung harus mempelajari bagaimana fungsi alat itu bekerja. Selain memudahkan pekerja dalam hal kinerja, kehadiran alat-alat baru seiring waktu mengambil fokus pekerja dan secara tidak sadar mereka terbuai dengan kemudahan teknologi dan manager maupun bos menjadi mudah dalam mengatur sistem di tempat kerja.

"disini kan ownernya barengan mbak, jadi mereka menghandle sendiri tapi bagi-bagi tugas gitu, kalau yang paling deket sama anak-anak ya bagian SDM itu sih, bagiku hampir sama kayak manager soalnya yang ngatur semuanya di kedai juga bagian SDM ini. Orangnya enakan kok Cuman ya tetep aja kita ga bisa ambil jatah minum/snack lebih dari satu, padahal menurutku kita juga pingin dimanjain dengan ambil jatah itu, tapi balik lagi sih kalo itu, kesadaran diri kita yang Cuma sebagai pegawai" (wawancara Lala 2021).

Penjelasan pembahasan sebelumnya mengenai gaji, peraturan kerja, serta kebijakan pekerja paruh waktu, menjadikan hal tersebut suatu pola yang umum di setiap tempat kerja. Pemilik tempat kerja yang memiliki andil lebih besar dapat menggunakan pola tersebut sebagai dominasi dan memajukan usahanya. Dominasi yang dilakukan seringkali tidak memperhatikan pekerja nyaman atau tidak karena pada dasarnya pemilik tempat kerja lebih banyak fokus kepada kemajuan bisnis daripada kekeluargaan.

\subsubsection{Pola Kekuasaan dari Sudut Pandang Pemilik Tempat Kerja}

Dasar hubungan pemilik modal adalah terletak pada kemampuan ekonomi yang dimiliki, sebaliknya buruh tidak memiliki kemampuan kekuasaan tersebut sehingga ia membalas jasa dengan kesetiaan serta kinerja. Unsur timbal balik tersebut lah yang membedakan antara bos dan buruh. Perbedaan status sosial tersebut tidak menyebabkan jarak antara bos dan buruh karena acuan kehidupan bermasyarakat adalah terletak pada nilai dan norma (Subang, n.d.). Pada prinsipnya pengusaha atau pemilik tempat kerja atau majikan adalah yang mengatur jalannya usaha tersebut. Pekerja/buruh bekerja di suatu tempat dengan dimana pengusaha sebagai pemberi upah maupun imbalan bentuk lain. Sedangkan pengusaha dapat disimpulkan sebagai seseorang yang mempekerjakan orang lain dengan memberikan gaji sesuai dengan kesepakatan awal dari kedua belah pihak (Unika, 1996).

Perusahaan dan karyawan memiliki peran sebagai simbiosis mutualisme. Apabila karyawan berhasil melakukan tugasnya dan berdampak bagi perusahaan, maka keduanya akan saling diuntungkan. Bagi karyawan, keberhasilan kerja merupakan bukti kemampuannya mengembangkan diri dan juga rasa tanggung jawab terhadap kebutuhan hidupnya. Sedangkan bagi organisasi, hal tersebut merupakan jembatan bagi perusahaan untuk dapat lebih maju (Pajak \& Zirman, 2013). Bos yang memiliki kedekatan dengan pekerjanya akan menciptakan lingkungan kerja yang nyaman, begitu sebaliknya.

"karyawan yang kerja disini normalnya ya memang harus mematuhi peraturan, ada sistem absen yang dimana kalau terlambat 5 menit dikenakan denda, dilarang bermain HP saat bekerja, terus 
harus pakai seragam, bersepatu dan tidak boleh ambil jatah makan karena memang disini nggak ada uang makan se mbak. Kalau dikatakan sebagai cara bos dalam berkuasa ya gimana ya mbak, kan pastinya ada peraturan itu juga menjadi hal yang wajar, kalau misalkan ada yang tidak srek, mereka juga ada evaluasi untuk menyampaikan. Kalau untuk dekat memang saya kurang terlalu dekat dikarenakan saya juga masih tahap belajar memulai bisnis ini dan saya orangnya agak pendiam jadi agak susah kalau mau friendly" (wawancara Pak Harianto selaku owner, 2021)

"saya itu nggak pernah ada istilahnya atasan dan karyawan mbak, saya menganggap mereka semua yang kerja disini itu keluarga, saudara. Tanpa mereka saya juga nggak bisa mengontrol usaha ini sendirian. Orientasi saya buka usaha juga bukan karena uang, tapi akhirat. Saya sering bertukar cerita sama anak-anak (pekerja), entah masalah pekerjaan maupun diluar ranah pekerjaan, mereka juga saya ajari bagaimana membuat resep, karena jika suatu hari ilmu yang saya amalkan itu digunakan oleh mereka itu kan sudah menjadi suatu amal jariyah bagi saya. Saya juga sering main ke rumah mereka kok. Jadi meskipun hubungan kita tanpa batas, tapi mereka itu masih ngajeni sama saya" (wawancara Pak Rendra selaku owner, 2021)

Sebagai pemilik tempat usaha, bos merasa hal yang dilakukan adalah hal yang wajar. Sistem yang diberikan tidak lain adalah dengan tujuan untuk memajukan usaha. Sehingga adanya evaluasi serta komunikasi yang baik diperlukan dalam suatu lingkungan kerja, hal tersebut bertujuan untuk dapat menemukan titik temu antara keinginan bos serta karyawan.

"saya mengajari karyawan saya untuk menjaga kekeluargaan dalam hubungan kerja, jadi biasanya ada komunikasi seminggu sekali serta evaluasi pekerjaan. Kalau kedekatan sudah saya anggap seperti keluarga, tapi memang ada beberapa karyawan yang belum dekat dengan saya dan saya juga tidak memaksa" (wawancara Fuad selaku owner, 2021).

Evaluasi perlu dilakukan oleh bos bersama karyawan dalam lingkungan kerja untuk mendapatkan satu tujuan dan visi yang sama, selain itu diperlukan juga komunikasi yang baik untuk menghindari adanya konflik. Komunikasi yang dilakukan hendaknya bukan sekedar urusan pekerjaan saja tetapi lebih kepada kedekatan yang intensif sehingga membangun rasa nyaman antar satu sama lain. Tidak hanya itu, dalam tempat kerja juga terdapat manager atau spv yang bertugas menjadi tangan kanan bos dalam mengatur sistem di lingkungan kerja. Hal tersebut sama seperti yang disampaikan oleh Braverman (1974) dalam teori Tenaga Kerja dan Monopoli Modal dimana pemilik kekuasaan dapat melakukan pengendalian manjerial atau menyerahkan tugasnya kepada manajer.

\section{Simpulan}

Keberadaan pemilik tempat kerja yang memiliki andil lebih besar menyebabkan adanya dominasi terhadap pekerja paruh waktu. Dominasi tersebut paling dirasakan pada ketentuan gaji yang selalu dibawah UMR, peraturan kerja yang mengikat serta kebijakan yang lebih banyak menguntungkan pemilik tempat kerja dikarenakan tidak adanya UU yang jelas mengatur mengenai kesejahteraan pekerja paruh waktu. Dinamika mahasiswa pekerja paruh waktu menjadi sebuah tantangan tersendiri bagi setiap individu, dunia pendidikan yang harus ditempuh hingga lulus harus diimbangi dengan manajemen waktu bekerja yang baik pula. Pola kekuasaan yang diberikan pemilik tempat kerja menjadi sebuah tantangan, tekanan dan pelajaran yang dapat membentuk pribadi mahasiswa dalam beradaptasi di dunia kerja. Sehingga diperlukan adanya komunikasi intensif yang baik untuk membangun kedekatan serta menghindari konflik.

Bagi penelitian selanjutnya hendaknya lebih mendalami bagaimana strategi pemilik tempat kerja dalam melakukan dominasi serta kapitalisme di era modern ini terhadap pekerja paruh waktu yang memiliki kedudukan rentan akan kesejahteraan. Dengan adanya 
pengetahuan mengenai bagaimana pemilik tempat kerja melakukan dominasi, bisa menjadi acuan mahasiswa pekerja paruh waktu di luar sana dalam menambah informasi sehingga sistem kapitalisme tidak hanya lebih menguntungkan satu pihak saja.

\section{Ucapan Terima Kasih (Opsional)}

Dengan diselesaikannya jurnal ini, saya mengucapkan syukur alhamdulillah kepada Allah Swt yang telah memberikan rahmat serta hidayahnya, kesehatan serta kelancaran dalam proses pengerjaan jurnal ini dan selalu memberi kesabaran serta kekuatan kepada diri ini untuk tidak menyerah. Saya ucapkan terimakasih kepada kedua orang tua saya yang telah memberikan kasih sayangnya yang tulus kepada saya hingga saya sampai pada titik ini, terima kasih sudah berkorban segalanya untuk saya dan juga saudar-saudara saya dalam menempuh pendidikan.

Tidak lupa pula saya ucapkan terimakasih kepada dosen pembimbing Bapak Nanda Harda Pratama Meiji beserta Bapak Nur Hadi yang sudah membimbing dengan baik selama proses penulisan jurnal ini hingga selesai. Terimakasih saya ucapkan pula kepada dosen-dosen jurusan sosiologi beserta teman-teman sosiologi angkatan 2017 yang memberikan support selama masa perkuliahan.

\section{Daftar Rujukan}

Afriansyah, A. (2017). Konsep Pemimpin Ideal Menurut Al-Ghazālī. NALAR: Jurnal Peradaban dan Pemikiran Islam, 1(2), 82-94.

Almigo, N. (2004). Hubungan antara kepuasan kerja dengan produktivitas kerja karyawan. Jurnal Psyche, 1(1), 50-60.

Aricahyani, F. (2019). Sistem Pemberian Upah Pekerja dalam Kaitannya dengan Kesejahteraan Pekerja ditinjau dari Perspektif Ekonomi Islam (Studi Kasus di Pasar Wage Tulungagung).

Ario, T. S., \& Anganthi, N. R. N. (2020). Problematika pada Mahasiswa Pekerja Paruh Waktu (Doctoral dissertation, Universitas Muhammadiyah Surakarta).

Badan Pusat Statistik. 2019. Angkatan Kerja di Kota Malang, Jawa Timur, dan Indonesia Menurut Pendidikan, 2011-2020. BPS Kota Malang. URL : https://malangkota.bps.go.id/indicator/6/442/1/angkatan-kerjadi-kota-malang-jawa-timur-dan-indonesia-menurut-pendidikan.html

Dirmantoro, M. (2015). Motivasi mahasiswa kuliah sambil bekerja (Doctoral dissertation, Universitas Islam Negeri Maulana Malik Ibrahim).

Firdaus, A. (2017). Hubungan Sosial Bos dengan Anak Buah Dalam Usaha Pertambangan Emas di Nagari Lubuk Ulang Aling Selatan, Kecamatan Sangir Batang Hari, Kabupaten Solok Selatan (Doctoral dissertation, STKIP PGRI Sumatera Barat).

Indra, C. A. (2013). Implikasi terbitnya regulasi tentang pertimahan terhadap hubungan bos dan anak buah: (Sebuah Egalitarianisme Lokal). Society, 1(1), 19-26.

Istarno, R. (2016). Kekuasaan pemilik modal dalam struktur kapitalisme media (Studi Ekonomi Politik Produksi Konten Surat Kabar Radar Banten). LONTAR: Jurnal Ilmu Komunikasi, 4(2).

Kamahi, U. (2017). Teori kekuasaan michael foucault: tantangan bagi sosiologi politik. Jurnal Al-Khitabah, 3(3).

Kirom, S. (2013). Buruh Dan Kekuasaan: Dinamika Perkembangan Gerakan Serikat Pekerja Di Indonesia (Masa Kolonial-Orde Lama). Avatara, 1(1), 9-15.

Kuslarassakti, M. P., \& Sutopo, O. R. (2020). Mobilitas dan Refleksivitas: Strategi Pemuda Yogyakarta di Masa Transisi menuju Dunia Kerja. JSW (Jurnal Sosiologi Walisongo), 4(1), 87-100.

Manurung, N. (2017). Sistem Pendukung Keputusan Pemberian Bonus Karyawan Menggunakan Metode Ahp. JurTI (Jurnal Teknologi Informasi), 1(1), 48-53.

Meiji, N. H. P. (2019). Pemuda (Pe) kerja Paruh Waktu: Dependensi dan Negosiasi. Jurnal Studi Pemuda, 8(1), 15-28. 
Jurnal Integrasi dan Harmoni Inovatif Ilmu-Ilmu Sosial, 1(5), 2021, 566-581

Moleong, Lexy. (2016). Metodologi Penelitian Kualitatif Edisi Revisi. Bandung: PT. Remaja Rosdakarya.

Neri, C. (2014). Pola Hubungan Antara Nelayan Pemilik Modal Dengan Nelayan Buruh Di Nagari Sungai Tunu Barat Kecamatan Ranah Pesisir Kabupaten Pesisir Selatan (Doctoral dissertation, STKIP PGRI Sumatera Barat).

Nurnazmi, N., Syaifullah, S., \& Waluyati, I. (2019). Pola Hubungan Antara Buruh Tenun (Tembe Nggoli) Dengan Pemilik Modal Di Kelurahan Rabadompu Barat Kecamatan Raba Kota Bima. Jurnal Darussalam: Jurnal Pendidikan, Komunikasi dan Pemikiran Hukum Islam, 11(1), 242-261.

Putri, S. H. (2020). Hubungan kerja antara juragan dan anak bagan dalam kehidupan nelayan. Jurnal Sosial Humaniora, 11(1), 15-28. 